Judicial fragmentation on indigenous property rights: causes, consequences and solutions

\author{
Elena Abrusci
}

School of Law, University of Nottingham, United Kingdom

Elena.Abrusci@nottingham.ac.uk

Published in:

The International Journal of Human Rights, Vol. 21, Issue 5 (2017) 


\title{
Judicial fragmentation on indigenous property rights: causes, consequences and solutions
}

\begin{abstract}
This paper engages in the analysis of the phenomenon of judicial fragmentation as affecting the case-law of regional human rights bodies on indigenous property rights. It aims at identifying the features of such divergent understanding of indigenous rights between the European Court of Human Rights and the InterAmerican Court of Human Rights, investigating the causes behind it. Finally, after having highlighted some of the adverse consequences of judicial fragmentation, the article presents some possible solutions for ensuring convergence and a higher standard of protection for indigenous rights.
\end{abstract}

Keywords: indigenous rights, judicial fragmentation, regional systems

\section{Introduction}

Judicial fragmentation is defined as the phenomenon arising when two courts seized of the same (or similar) matter issue contrasting or conflicting judgments. ${ }^{1}$ Said otherwise, judicial fragmentation is the consequence of different judicial interpretations of similar provisions by two or more judicial bodies. As highlighted by some scholars, ${ }^{2}$ this is not a predominant phenomenon within International Human Rights Law but it does affect specific rights, especially if looking at the case-law of regional human rights bodies. The regional jurisprudence of the European, Inter-American and African systems on indigenous property rights offers an emblematic example of such fragmentation.

The complex matter of the communal and ancestral right to property for indigenous people has been widely discussed by scholars and practitioners ${ }^{3}$ and it is still

${ }^{1}$ Cfr. Philippa Webb, International Judicial Integration and Fragmentation (Oxford University Press, 2013).

${ }^{2}$ Marjan Ajevski, Fragmentation in International Human Rights Law: Beyond Conflict of Laws (Routledge, 2015)

${ }^{3}$ Cfr. Alexandra Xanthaki, Indigenous rights and United Nations standards: self-determination, culture and land (CUP, 2007); Ann Curthoys, Ann Genovese and Alexander Reilly, Rights and Redemption: History, Law and Indigenous People, (UNSW Press, 2008); Stan Stevens, Indigenous Peoples, National Parks and Protected Areas: a New Paradigm Linking 
in the process of being adequately protected by international rules. Indeed, the UN Declaration on the Rights of Indigenous People (UNDRIP) ${ }^{4}$ was adopted only in 2007 and the ILO Convention No. 169 on Indigenous and Tribal people's rights ${ }^{5}$ has been ratified so far by merely 22 countries. Cultural and historical variables play a key role in recognizing the right to communal property for indigenous people. Indeed, while indigenous communities and minority groups are a reality everywhere, the fact that these groups have had a fundamental role in the history of Latin America and Africa, compared to the history of Europe, significantly affected the protection of their rights especially in the judicial interpretation of regional human rights bodies.

The right to property is similarly articulated in regional human rights instruments; namely Article 14 of the African Charter, Article 21 of the American Convention and Article 1 of the First Protocol to the European Convention on Human Rights. Whilst these instruments slightly differ in the text, they all establish the principle that everyone should have the right to use and enjoy his property within the limits that the State may impose on certain legitimate grounds. ${ }^{6}$

Conservation, Culture and Rights, (University of Arizona Press, 2014); Roger Plant, Land rights and minorities (London Minority Group, 1994) and Jo M. Pasqualucci 'International indigenous Land Rights: a critique of the jurisprudence of the Inter-American Court of Human Rights in light of the United Nations Declaration on the Rights of Indigenous Peoples' Wisconsin International Law Journal 27 (2010) 51.

${ }^{4}$ UN General Assembly, United Nations Declaration on the Rights of Indigenous People, A/RES/61/295, adopted on $2^{\text {nd }}$ October 2007, hereinafter UNDRIP.

${ }^{5}$ International Labour Organization (ILO), Indigenous and Tribal Peoples Convention, C169, 27 ${ }^{\text {th }}$ June 1989, hereinafter ILO Convention 169.

${ }^{6}$ Article 14 of the African Charter of Human and People's Rights states: "The right to property shall be guaranteed. It may only be encroached upon in the interest of public need or in the general interest of the community and in accordance with the provisions of appropriate laws."

Article 21 of the American Convention on Human Rights states: "1.Everyone has the right to the use and enjoyment of his property. The law may subordinate such use and enjoyment to the interest of society. 2. No one shall be deprived of his property except upon payment of just compensation, for reasons of public utility or social interest, and in the cases and according to the forms established by law. 3. Usury and any other form of exploitation of man by man shall be prohibited by law."

Article 1 of the First Protocol to the European Convention on Human Rights states: "1. Every natural or legal person is entitled to the peaceful enjoyment of his possessions. No one shall 
However, the application of such provisions in the specific case of land claims by indigenous groups did reveal a noteworthy difference in the approach towards the right to collective property of ancestral lands as well as a different understanding of the meaning of property for indigenous people.

This analysis will consider the case-law on indigenous land rights of the European Court of Human Rights (ECtHR), the Inter-American Court of Human Rights (IACtHR) and the African Commission of Human and People's Rights (ACommHPR), revealing how the European Court is still overly attached to a private conception of the property and is reluctant to adapt its jurisprudence to the other regional systems.

The second part will then attempt to identify some of the possible causes and consequences of judicial fragmentation, ranging from legal to political and sociological concerns.

In conclusion, after a further discussion of the existing international framework on indigenous rights, it will be argued that the transformation of the UNDRIP into a proper binding treaty and the increasing lobbying and pressure from NGOs and civil society on the European Court could be two possible solutions for significantly reducing judicial fragmentation.

be deprived of his possessions except in the public interest and subject to the conditions provided for by law and by the general principles of international law. 2. The preceding provisions shall not, however, in any way impair the right of a State to enforce such laws as it deems necessary to control the use of property in accordance with the general interest or to secure the payment of taxes or other contributions or penalties. 


\section{Indigenous property rights before regional human rights courts}

\section{The European Court of Human Rights}

The right to property under the European Convention on Human Rights (ECHR) is regulated by Article 1 of the First Protocol which states:

'Every natural or legal person is entitled to the peaceful enjoyment of his possessions. No one shall be deprived of his possessions except in the public interest and subject to the conditions provided for by law and by the general principles of international law. The preceding provisions shall not, however, in any way impair the right of a State to enforce such laws as it deems necessary to control the use of property in accordance with the general interest or to secure the payment of taxes or other contributions or penalties.'

The provision seems quite generic, leaving significant power for states to interfere with private property. Moreover, the lack of any express reference to a right to compensation, with the exception of the very general mention to principles of international law, is the consequence of a highly debated drafting process that ended up with a cautious formulation.

Article 1 Protocol 1 ECHR, as well as the rest of the European Convention, did not make any reference to indigenous people or community, leaving a very wide margin of interpretation to the ECtHR in adjudicating indigenous property claims.

The European Court have made significant progresses from the position of its predecessor, the European Commission, that stated in 1983, in G. and E. v Norway, that the 'Convention does not guarantee specific rights to minorities' ${ }^{8}$ However, the two

\footnotetext{
${ }^{7}$ Council of Europe, European Convention for the Protection of Human Rights and Fundamental Freedoms, as amended by Protocols Nos. 11 and 14, 4 November 1950, Article 1 Protocol 1. ${ }^{8}$ G. and E. v Norway, Application no 9278/81, 9415/81 (ECommHR, 1983), 30.
} 
recent cases, Hingitaq 53 and Others $v$ Denmark ${ }^{9}$ and Handölsdalen Sami Village and Others $v$ Sweden ${ }^{10}$ show that the protection granted to indigenous people claiming their right to property on the ancestral lands in Europe is still insufficient compared to the protection ensured in Africa or America, thus producing a situation of judicial fragmentation. ${ }^{11}$

The Hingitaq 53 case concerned the claims of the Thule Tribe (a group of Inghuit) who claimed that the dispossession of their aboriginal lands by Denmark violated the right to a peaceful enjoyment of possessions under Article 1, Protocol 1 ECHR. In 1951, Denmark decided to grant access to the United States to establish an air base in the Thule District and in 1953 allowed the US expanding the base across the entire District, thus forcing the Inughuit to leave their homes and settle in different areas where they could not perform any of their traditional activities. The European Court recognized that the Thule Tribe had an existing possession prior to the establishment of the air base but it concluded that the expropriation was not an arbitrary measure since it was meant to satisfy a public interest that, at the time, was 'legal and valid' ${ }^{12}$ Moreover, the Court acknowledged that the circumstances of the Cold War had justified the decision of Denmark and assessed that the applicants had received proper compensation for all the damages and losses, thus striking a fair balance between the interests at stake. ${ }^{13}$ In light of the above, the ECtHR rejected the application as being manifestly ill-founded. Furthermore, while the ECtHR did recognize, in theory, the specific communal rights of

\footnotetext{
${ }^{9}$ Hingitaq 53 and Others $v$ Denmark, Application no 18584/04 (ECtHR, 12 January 2006).

${ }^{10}$ Handölsdalen Sami Village and Others v. Sweden, Application no 39013/04 (ECtHR, 30 March 2010).

${ }^{11}$ Cfr. Timo Koivurova, 'Jurisprudence of the European Court of Human Rights Regarding Indigenous Peoples: Retrospect and Prospects', International Journal on Minority and Group Rights 18 (2011): 1-37.

${ }^{12}$ Hingitaq 53 and Others $v$ Denmark, The Fact, A.

${ }^{13}$ ibid, The Law, A.
} 
indigenous communities, it ended up not to apply them in the present case on the basis of the status of the Thule tribe. The Court argued that the latter did not retain 'some or all of its own social, economic, cultural and political institutions' needed for qualifying as a distinct community from the overall indigenous community inhabiting Greenland under Article 1(1)(b) of the ILO Convention 169, thus concluding that the ECtHR could not take a position in relation to the claim 1 and 2 of the case. ${ }^{14}$

The only other relevant case of the European Court on the matter is Handölsdalen Sami Village and Others $v$ Sweden. It concerned domestic proceedings about a disputed right of the Sami to use their ancestral land for winter grazing of their reindeers. Many landowners brought proceedings against Sami villages, including the applicants, seeking a judgment forbidding them from using the land without a proper contract with the respective owners. The issue was brought in front of national courts that found against the applicants, imposing significant fines on the Sami communities. The European Court, whilst recognizing that possessions for the application of Article 1 First Protocol include tangible as well as intangible goods ${ }^{15}$, assessed that the Sami's claim for winter grazing rights in private property should not be regarded as an asset but rather a possession. The ECtHR required the Sami to prove such existing possession over the claimed land since a possession must be existing in order to receive legal protection. ${ }^{16}$ However, the Court held that the Sami were not able to provide such proof and, in light of this, it rejected the

${ }^{14}$ The complainant brought four claims as follows: 1) that they had the right to live in and use their native settlement in Ummannaq/Dundas in the Thule District; 2) that they had the right to move, stay and hunt in the entire Thule District; 3) that the Thule Tribe was entitled to compensation in the amount of DKK 25.000 .000 and 4) that each individual was entitled to compensation in the amount of DKK 250.000.

${ }^{15}$ See, e.g., Bramelid and Malmström v. Sweden, Application no 8588/79 and 8589/79 (ECtHR, 1982)[Admissibility], The Law, 1 b; Smith Kline and French Laboratories v. the Netherlands Application no. 12633/87 (ECtHR, 1990) The Law and Stran Greek Refineries and Stratis Andreadis v. Greece (Merits), Application no 13427/87, (ECtHR, 1994), 61-62.

${ }^{16}$ Marckx v Belgium Application no 6833/74 (ECtHR, 13 June 1979), 50 and Xv Federal Republic of Germany, Application no 8410/78 (ECtHR, 1979), 2. 
claims as being incompatible ratione materiae with the provisions of the ECtHR. ${ }^{17}$ The only contrasting voice was that of Judge Ziemele who, in her dissenting opinion, pointed out that the reasoning of the ECtHR did not take into consideration the specific features and rights of indigenous people. ${ }^{18}$ Recalling the development in the international framework on indigenous rights, namely the ILO Convention NO. 169 and the UNDRIP as approved by the General Assembly, Judge Ziemele observed that the burden of proof imposed on the Sami villages was too high and not adequate for the nature of their claim, thus discriminating the Sami villages compared to an individual litigant in Sweden. ${ }^{19}$ The dissenting opinion concluded that the ECtHR should have recognized 'the right of indigenous peoples to own the land which such groups have traditionally used and to engage in traditional economic activities ${ }^{, 20}$ and the legal technicalities that prevent this amount to a violation of the right to fair trial and access to justice. ${ }^{21}$

\section{The Inter-American Court of Human Rights}

The Inter-American Court of Human Rights is the regional court that developed most of its jurisprudence on indigenous property rights. Article 21 of the American Convention on Human Rights (ACHR) states:

'Everyone has the right to the use and enjoyment of his property. The law may subordinate such use and enjoyment to the interest of society. No one shall be deprived of his property except upon payment of just compensation, for reasons of public utility or social interest, and in the cases and according to the

\footnotetext{
${ }^{17}$ Handölsdalen Sami Village and Others v. Sweden [Admissibility], 56.

${ }_{18}^{18} \mathrm{ibid}$, dissenting opinion Judge Ziemele, 5.

${ }^{19}$ Ibid 2-7.

${ }^{20}$ Ibid 2.

${ }^{21}$ Ibid 8-10.
} 
forms established by law. Usury and any other form of exploitation of man by man shall be prohibited by law. ${ }^{22}$

Ruling on a significant number of cases on the matter, the IACtHR had the chance to discuss widely the extent of the right to property of indigenous people, going well beyond the letter of the provision contained in the American Convention.

Of particular relevance for the current analysis are five cases decided by the InterAmerican Court: Mayagna (Sumo) Awas Tingni Community v Nicaragua ${ }^{23}$, Yake Axa Indigenous Community $v$ Paraguay ${ }^{24}$, Sawhoyamaxa Indigenous Community $v$ Paraguay $^{25}$, Saramaka $v$ Suriname $^{26}$ and Kichwa Indigenous People of Sarayaku $v$ Ecuador $^{27}$.

The Awas Tigni case, in 2001, was a seminal case for the Inter-American human rights system and for the rights of indigenous people since the Court recognized, for the first time, that indigenous people do have a collective right to property on their ancestral land even if not officially recognized by the state. The facts were similar to the Hingitaq 53 case. They concerned the complaints filed by the Mayagna (Sumo) Awas Tingni Community against the Government of Nicaragua for having forced them to leave their ancestral lands after granting logging concessions to private owners. However, in contrast to the ECtHR, the IACtHR decided to clearly support the indigenous claims by stating that 'indigenous people, by the fact of their very existence, have the right to live freely in their own territory; the close ties of indigenous people with the land must be recognized and understood as the fundamental basis of their cultures, their spiritual life, their

22 Organization of American States (OAS), American Convention on Human Rights, "Pact of San Jose", Costa Rica, 22 November 1969, Article 21.

${ }^{23}$ Mayagna (Sumo) Awas Tingni Community v Nicaragua (IACtHR, 31 August 2001).

${ }^{24}$ Yake Axa Indigenous Community v Paraguay (IACtHR, 17 June 2005).

${ }^{25}$ Sawhoyamaxa Indigenous Community v Paraguay (IACtHR, 29 March 2006).

${ }^{26}$ Saramaka People v Suriname (IACtHR, 28 November 2007).

${ }^{27}$ Kichwa Indigenous People of Sarayaku v. Ecuador (IACtHR, 27 June 2012). 
integrity, and their economic survival. ${ }^{28}$ The Court also stressed that the protection of communal lands was afforded 'through an evolutionary interpretation of international instruments $[\ldots]$ which precludes a restrictive interpretation of the rights ${ }^{29}$ and held that 'possession of the land should suffice for indigenous communities lacking real title to property of the land to obtain official recognition' of ownership. ${ }^{30}$ Furthermore, the IACtHR clarified that the right to property as contained in international human rights treaties has an autonomous meaning and 'cannot be made equivalent to the meaning given [...] in domestic law, ${ }^{31}$ This is significantly different from the understanding of property within the case-law of the European Court that relies heavily on the decision of domestic courts for the determination of the meaning of possession. ${ }^{32}$ However, the Court kept a veil of uncertainty by citing Article 29 ACHR which restrict 'the enjoyment or exercise of any right or freedom recognise by virtue of the laws of any State or by virtue of another convention to which one of the said states is a party'. ${ }^{33}$ In light of the domestic legislation of Nicaragua, recognizing communal property, the Court concluded that it was obliged to take the communal property dimension into account when interpreting Article $21 .^{34}$ Luckily, this gap was soon filled in Moiwana Village $v$ Suriname, where the IACtHR held that Article 21 unconditionally entails the right to communal property, regardless of national legislation. ${ }^{35}$

${ }^{28}$ Mayagna (Sumo) Awas Tingni Community v Nicaragua , 149.

${ }^{29}$ ibid, 148.

${ }^{30}$ ibid, 151.

${ }^{31}$ ibid, 146.

${ }^{32}$ Giovanna Gismondi, 'Denial of Justice: The Latest Indigenous land Disputes Before the European Court of Human Rights and the Need for an Expansive Interpretation of Protocol 1' Yale Human Rights and Development Law Journal 18 (2015), 42.

${ }^{33}$ American Convention on Human Rights, Article 29.

${ }^{34}$ Thomas M. Antkowiak, 'Rights, Resources, and Rhetoric: Indigenous Peoples and the InterAmerican Court', University of Pennsylvania Journal of International Law 13, no. 2 (2014): 143-144.

${ }^{35}$ Moiwana Cmty v. Suriname (Moiwana Village) (IACtHR, 15 June 2005), 86 (5). 
Yake Axa Indigenous Community v Paraguay is another significant judgment for the development and strengthening of indigenous land rights. Here the Court dealt with a dispute between private landowners and the Yakye Axa indigenous Community, in a way similar to Handölsdalen. In supporting the position of the applicant, the IACtHR warned its member states to recognize the fact that indigenous population have specific features that differ from the general population. Moreover, the Court connected the right to access to traditional lands with the surrounding habitat, holding that 'states must take into account that indigenous territorial rights encompass a broader and different concept that relates to the collective right to survival as an organized people, with control over their habitat as a necessary condition for reproduction of their culture, for their development and to carry out their life aspirations' ${ }^{36}$ States have a duty to 'take positive, concrete measures geared toward fulfilment of the right to a decent life, especially in the case of persons who are vulnerable and at risk' such as indigenous people; a failure to do so will constitute a violation of the right to vida digna and therefore Article 4. In addition, the Inter-American Court held that, when returning to ancestral lands is not possible, the selection of the alternative lands and/or the compensation are not left to the discretion of the state but should be the result of a 'consensus with the indigenous people in accordance with their own mechanism of consultation, values, customs and customary law'. ${ }^{37}$ This is an alternative stance from the one of the ECtHR in Hingitaq 53, where nothing was said about the imposed choice of alternative lands and amount of compensation made by Denmark. $^{38}$

\footnotetext{
${ }^{36}$ Yake Axa Indigenous Community v Paraguay, 146.

37 ibid, 149-151.

${ }^{38}$ G Otis and A Laurent, 'Indigenous Land Claims in Europe: The European Court of Human Rights and the Decolonization of Property', Arctic Review on Law and Politics 4, no. 2 (2013): 156-80, http://arcticreview.no/index.php/arctic/article/download/47/47; Birgitte Feiring, Indigenous Peoples' Rights to Lands, Territories and Resources, 2013.
} 
In Sawhoyamaxa, the Inter-American Court adopted a diametrically opposed position compared to the European Court's position in Hingitaq 53. Here the IACtHR asserted that 'communities who have unwillingly left their traditional lands, or lost possession thereof, maintain property rights thereto, even though they lack legal title; $[\ldots]$ and who have unwillingly lost possession of their lands, when those lands have been lawfully transferred to innocent third parties, are entitled to restitution thereof or to obtain other lands of equal extension and quality'. ${ }^{39}$ Moreover, while dealing with a claim arising out of a dispute between private parties and indigenous communities, the Court said that it must 'assess in each case the legality, necessity, proportionality and fulfilment of a lawful purpose in a democratic society to impose restriction on the right to property, on the one hand, or the right to traditional lands, on the other'. As some scholars pointed out, ${ }^{40}$ in Handölsdalen, the ECtHR should have consider also the right of the Sami people to their cultural integrity in striking a fair balance with the right to property of the landowners.

Saramaka $v$ Suriname reinforced all the previous concepts and reaffirmed the strong position of the Inter-American Court in recognizing full ancestral land rights to indigenous communities. Here the Court deeply linked the right to property with the right to use and enjoy natural resources in a way that, if endorsed by the European Court, would have produced a different outcome in the Handölsdalen case. Indeed, the IACtHR stated that the protection of the communal lands was 'necessary to guarantee their [Saramaka people] survival' and, more importantly, that 'the right to the land itself would be "meaningless" without rights to the natural resources therein'. ${ }^{41}$ Therefore, the InterAmerican Court interpreted the right to property as protecting also those 'resources

\footnotetext{
${ }^{39}$ Sawhoyamaxa Indigenous Community v Paraguay, 128.

${ }^{40}$ Otis and Laurent, ' Indigenous Land Claims in Europe', 157; Koivurova, ' Jurisprudence of the European Court of Human Rights', 137.

${ }^{41}$ Saramaka People v Suriname, 122.
} 
traditionally used and necessary for the very survival, development and continuation of such people's way of life', thus extending its definition of vida digna. ${ }^{42}$ Moreover, in the same case, which concerned the granting of logging and mining concessions to private companies in a traditional territory without prior consultation with the indigenous people, the IACtHR established that the State is required to implement some safeguards in order to protect the rights and interests of the affected indigenous populations. ${ }^{43}$ Compared to both Hingitaq 53 and Handölsdalen, it is evident how the ECtHR did not engage in any of this discussion and did not feel the need to set any safeguards for the protection of indigenous people's rights when ruling against them.

The most recent case on the matter is Kichwa Indigenous People of Sarayaku $v$ Ecuador $^{44}$, issued in 2012. In this case Ecuador did recognize the communal property of the Sarayaku but retained a number of rights, including the exploitation of subsurface natural resources. ${ }^{45}$ The ruling in favour of the applicants confirmed that Article 21 protects communal property and held, for the first time, that it was the Sarayaku community as indigenous community, rather than just the sum of individuals, who suffered a collective violation. ${ }^{46}$ Moreover, the Court stressed the importance of the 'right to consultations' and effective participation of the indigenous community whose

\footnotetext{
42 ibid.

43 "First, the State must ensure the effective participation of the members of the Saramaka people, in conformity with their customs and traditions, regarding any development, investment, exploration or extraction plan (hereinafter "development or investment plan") within Saramaka territory. Second, the State must guarantee that the Saramakas will receive a reasonable benefit from any such plan within their territory. Thirdly, the State must ensure that no concession will be issued within Saramaka territory unless and until independent and technically capable entities, with the State's supervision, perform a prior environmental and social impact assessment. These safeguards are intended to preserve, protect and guarantee the special relationship that the members of the Saramaka community have with their territory, which in turn ensures their survival as a tribal people." ibid,127-129.

${ }^{44}$ Kichwa Indigenous People of Sarayaku v. Ecuador, (IACtHR, 27 June 2012).

${ }^{45}$ Ibid 61-72.

${ }^{46}$ Ibid 341 (2).
} 
traditional lands are put at risk $^{47}$, considering it not only provided by the American Convention but a 'general principle of international law'. ${ }^{48}$

\section{The African Commission of Human and People's Rights}

The African Commission of Human and People's Rights followed the progressive line of interpretation of the Inter-American Court, thus diverging considerably from the position of the European Court. The African Charter on Human and People's Rights provides, in Article 14, that: 'The right to property shall be guaranteed. It may only be encroached upon in the interest of public need or in the general interest of the community and in accordance with the provisions of appropriate laws. ${ }^{49}$ The Endorois case concerned the displacement of the indigenous community Endorois from their ancestral lands following the decision of the Government of Kenya to convert the area in a national reserve for conservation purposes. ${ }^{50}$ Here the Commission took a clear stance in favour of the Endorois community. It openly recognized that the 'the encroachment on Endorois land was not proportional to any public need and not in accordance with national and international law, ${ }^{51}$ and ordered Kenya to return the lands to the community. By frequently referring to the case-law of the Inter-American Court, the African Commission recognized that the right to property should be guaranteed to the indigenous community even if the domestic legislation does not recognize collective rights. In 2012, the case was referred to the African Court of Human and People's Rights, becoming the first case on

\footnotetext{
${ }^{47}$ Ibid E.2.a.

${ }^{48}$ Antkowiak, 'Rights, Resources, and Rhetoric', 157.

${ }^{49}$ Organization of African Unity (OAU), African Charter on Human and Peoples' Rights ("Banjul Charter"), 27 June 1981, Article 14.

${ }^{50}$ Centre for Minority Rights Development (Kenya) and Minority Rights Group International on behalf of Endorois Welfare Council v. Kenya, Communicatio no 276/03 (ACommHPR, 25 November 2009), 3.

${ }^{51}$ ibid, 238
} 
indigenous rights to appear before the African Court. ${ }^{52}$ While the petition is still pending, the Court issued provisional measures after finding an extremely serious and urgent situation of human rights violations. ${ }^{53}$

\section{Case-law assessment}

In light of the above, it is possible to conclude that the protection of property rights for indigenous people is fragmented among regional human rights bodies.

From the previous analysis it seems quite clear that the key difference between the regional courts' approaches is that the European Court continues addressing indigenous land rights claim as any other private property rights case, without taking into serious consideration the features of the applicant.

In Hingitaq 53, when rejecting the case and considering the compensation and the alternative land received as proportionate for the Inghuit community, the ECtHR seemed to ignore the need of the indigenous community as such and treating it as any group of people being forced to leave their home. In contrast, both the Inter-American Court and the African Commission focused on the specific nature of an indigenous community and reflected on the importance of the land as part of their own culture, history and life. Not surprisingly, the Inter-American Court often linked the protection of indigenous ancestral land to the concept of vida digna, stating that the use and enjoyment of their ancestral land is fundamental to live a life with dignity. ${ }^{54}$

The same consideration can be made for the Handölsdalen case. Here, the ECtHR, when rejecting the case because the applicant was not able to demonstrate the existing

\footnotetext{
${ }^{52}$ African Commission on Human and People's Rights v The Republic of Kenya, Application No. 006/2012 (ACtHPR).

${ }^{53}$ Feiring, 'Indigenous Peoples' Rights to Lands, Territories and Resources', 34.

${ }^{54}$ Cfr. Xákmok Kásek v. Paraguay (IACtHR, 24 August 2010), 107.
} 
possession, did not consider the specificity of indigenous ancestral land rights. First, the Court did not recognize the right to collective property over an ancestral land in absence of a legal title. Second, it completely ignored the fact that for an indigenous community the use of the land for traditional activities is part of its own existence. In contrast, both the IACtHR and the ACommHPR reached the opposite conclusion when dealing with similar situations of a property right claim over a land that could not be legally justified and demonstrated. Indeed, they both concluded that the requirement of a legal title should be widely interpreted and that traditional activities connected to the land are fundamental for the survival of the indigenous community.

\section{Causes of judicial fragmentation}

The cause of the current situation of judicial fragmentation on indigenous property rights is certainly the different approach, on the one hand, of the progressive InterAmerican Court and African Commission and, on the other hand, of the conservative European Court. Still, the reasons behind the rigid and individualistic attitude of the European Court are not fully clear.

Certainly, the letter of the articles protecting the right to property can not be invoked as the sole cause of such divergent interpretation. Indeed, as previously recalled, Article 1 of the First Protocol to the ECHR is actually the most advanced and comprehensive right to property, especially in comparison to the African and American instruments for its explicit reference to the enjoyment of the property and to any "natural or legal person" as right holder. However, the different regional framework on minority and indigenous rights should be taken into consideration. The little attention within the European system towards indigenous rights is demonstrated by the lack of any explicit reference to indigenous people in the Framework Convention for the Protection of National Minorities. While some indigenous groups can fit within the very broad 
definition of national minority, the absence of a clear mention to the rights of indigenous people in a specific instrument is an evident signal of the lack of interest towards this issue within the European system. Nonetheless, one should not ignore that even within the Inter-American and African system there is no specific reference to or convention on indigenous rights. Therefore, the argument of the different legal framework can only partially explain the phenomenon of fragmentation.

The margin of appreciation, often invoked in cases of fragmentation as a possible explanation, here finds little application. The European Court did grant a wide margin of appreciation to the states in defining the criteria for attributing the property and negotiating the reparations and the alternative lands, but it did not justify its outcome on this basis. Indeed, this element appears to be marginal for the current issue because, rather than deferring the decision to the national authorities through the tool of the margin of appreciation, the ECtHR seemed to have taken a quite clear stance on the matter of indigenous land rights.

The impression from the reading of the two judgments is that the European Court was not familiar with indigenous rights and did not know how to properly deal with collective and communal property claims and, opting for a cautious solution, decided to apply its well established reasoning and understanding of private property rights. The ECtHR relied on the principle of 'eminent domain', i.e. on the presumption of state monopoly over land, also applied to the territories claimed by indigenous communities. On the basis that the indigenous community could not provide any legal title of ownership over the land, the state should be considered as the lawful owner of that land and could dispose it freely, granting or allocating it to third parties. ${ }^{55}$

${ }^{55}$ Cfr. Otis and Laurent 158, Economic and Social Council, Commission on Human RIghts, SubCommission on the Promotion and Protection of Human Rights, $53^{\text {rd }}$ Session, Indigenous 
The general different sensibility and attention towards indigenous rights between the regional bodies is easily explained by the history and politics of the countries involved. American and African countries have dealt with indigenous issues for a long time and, currently, these are still at the forefront of the political and social agenda of national and regional institutions. Indigenous communities in Africa and in the Americas have played a significant role in the history and politics of the two continents and they still play a fundamental role in the society. The African and the Inter-American human rights systems have amongst their priorities the protection of the indigenous communities $^{56}$ and they actively contributed to the debate within the ILO and the UN bodies for the development of relevant international instruments. Therefore, it is not surprising that, in their judicial interpretation, the rights of the indigenous groups are applied and defended at the maximum level, setting a very high standard of protection.

\section{Consequences of judicial fragmentation}

The current situation of judicial fragmentation between, on the one hand, the European Court of Human Rights and, on the other hand, the Inter-American Court of Human Rights and the African Commission of Human and People's Rights is likely to produce adverse effects.

First, the different judicial protection granted to indigenous communities living in Europe compared to those living in the Americas or in Africa poses a significant threat to the principle of universality. Indigenous rights are, as any other human rights, 'universal,

Peoples and their Relationship to Land-Final working paper prepared by thr Special Rapporteur Mrs. Erica-Irene A. Daes, E/CN.4/Sub.2/2001/21.

56 A proof of this engagement is, for example, the establishment, by the Inter-American Commission, of the Special Rapporteur on the Rights of Indigenous People (http://www.oas.org/en/iachr/indigenous/mandate/Functions.asp) and, by the African Commission, of the Working Group on Indigenous Populations/Communities in African (http://www.achpr.org/mechanisms/indigenous-populations). 
indivisible and interdependent and interrelated'. ${ }^{57}$ As such, they should be interpreted and judicially applied by regional bodies in a way that ensure the maximum convergence, while respecting local peculiarities.

Second, the existing fragmentation between regional bodies, setting different standards of protection, could undermine the international protection of indigenous rights. The disagreement between regional bodies on the level of protection to be ensured could be easily used by states as an excuse for not complying with the demanding judgments or recommendations of the Inter-American and African bodies.

Third, the fact that the European Court did not refer to or acknowledged the welldeveloped Inter-American jurisprudence on indigenous rights, the ILO Convention No. 169 and the UNDRIP in its admissibility decisions is a strong signal of separation of the European system from the international framework. In addition, by ignoring the advanced and specific provisions contained in the ILO Convention No. 169 and in the UNDRIP, the ECtHR did in a way undermine their value and legitimacy as well as role in the international protection of indigenous rights. The ECtHR is a significant and authoritative body in human rights adjudication, often operating as a trend setter and is frequently imitated by other human rights bodies both at the international and domestic level. Continuing to do so will definitely aggravate the situation, making the two instruments impractical in practice when it comes to European indigenous communities.

Lastly, a problem within the existing judicial fragmentation could be for the IACtHR and the ACommHPR to reach convergence by conforming its jurisprudence to the ECtHR, thus reverting to a lower standard of protection. Even though this possibility may be unlikely for the strong relevance that indigenous matters have in the Americas

${ }^{57}$ UN General Assembly, Vienna Declaration and Programme of Action, A/CONF.157/23, 12 July 1993. 
and in Africa, the post-colonial influence that the European Court is exercising on the African human rights bodies may suggest the opposite..$^{58}$

\section{Possible solutions for judicial fragmentation}

Considering the possible consequences of the current fragmented picture of regional caselaw on indigenous property rights, the natural solution would be for the ECtHR to adopt a more progressive approach and align itself to the IACtHR and the ACommHPR.

As highlighted in the previous analysis, what the ECtHR missed is the recognition of the specificity of indigenous communities as subjects of law and bearer of particular rights. In particular, the protection of the right to collective property, especially when claimed by indigenous communities, has been the main challenge for the European Court.

The International framework on the rights of indigenous people already offers a welldeveloped protection, enough for allowing the ECtHR advancing its jurisprudence. However, the Strasbourg court, while sometimes acknowledging it, has always been quite reticent in accepting and adopting the standards contained therein.

The two main documents on this regard are the ILO Convention No.169 and the UN Declaration on the Rights of Indigenous People.

The ILO Convention No. 169 was approved in 1989 to update the existing norms protecting indigenous people contained in the ILO Convention No. 107. ${ }^{59}$ The latter was the first example of a binding international legal instrument completely dedicated to

${ }^{58}$ Unfortunately, the matter could not be discussed properly in this article. However, the alleged post-colonial heritage in the work of the African bodies can be observed, among others, in the Darfur case (Sudan Human Rights Organisation \& Centre on Housing Rights and Evictions (COHRE) v Sudan, Communications no. 279/03-296/05) where the African Commission refers to the ECtHR's judgment Selçuk and Asker v Turkey (Application no. 23184/9423185/94, 24 April 1998) to conclude that an eviction amounts to a torture, contrary to its own jurisprudence in Ogoniland case (Social and Economic Rights Action Centre (SERAC) and Another v Nigeria, Communication no. 155/96, 2001).

59 International Labour Organization (ILO), Indigenous and Tribal Populations Convention, C107, 26 June 1957. 
indigenous rights. However, it lacked any substantial protection for indigenous people and was considered by indigenous communities as an 'assimilationist' instrument that, rather than ensuring their rights and independence, it was inducing them to gradually join and conform to the national society. ${ }^{60}$ In this context, the Convention No. 169 was the result of several efforts of civil society pushing for the approval of a document that was properly ensuring indigenous rights. The Convention reiterated in any possible way the fundamental principle that states should address any indigenous rights claim bearing in mind the specificity of indigenous people compared to any other minority. Moreover, it dedicated an entire section to land claims, recalling the importance of the protection of collective property and ancestral use of land. ${ }^{61}$ Unfortunately, the Convention has been ratified so far only by 22 countries, thus making the instrument of little practical use. Moreover, while from a European perspective the text could look as a progressive manifestation of indigenous rights, it has received significant critics from indigenous communities. It has been argued that the Convention was a confirmation of the Eurocentric vision of indigenous matters, hiding the 'assimilation language' already criticised in the previous Convention No. 107. The unclear meaning of the term 'people' used in the Convention, the absence of an explicit reference to the right to selfdetermination, the lack of specific duties for the states to undertake proper consultation with the indigenous communities and the impossibility under the Convention to claim a property right on a land that is not currently occupied or used made indigenous people reject the ILO Convention. ${ }^{62}$ As Sharon Venne explicitly stated, the ILO Convention No.

${ }^{60}$ Gonzalo Aguilar Cavallo, Dinamica internacional de la cuestion indigena (Librotecnia, 2007).

${ }^{61}$ ILO Convention 169, Artt. 13-19.

${ }^{62}$ Sharon Venne, The New Language of Assimilation: A Brief Analysis of ILO Convention 169, Without Prejudice 53, no. 2 (1989), available at http://www. eaford.org/publications/3/WITHOUT\%20Prejudice\%20Vol_II_No2.pdf. 
169 should be considered as a legalized step backwards for indigenous rights and a further attempt to undermine indigenous people worldwide. ${ }^{63}$

The UNDRIP, adopted in 2007 after many years of negotiation, represented a step forward in the advancement of indigenous rights. As pointed out by many commentators, the key principle when it comes to indigenous rights is the right to 'self-determination'. Absent in the ILO Convention No. 169, the right to self-discrimination for indigenous people is explicitly stated in Article 3 where is provided that indigenous people have the right to 'freely determine their political status and freely pursue their economic, social and cultural development'. ${ }^{64}$ Moreover, the UNDRIP addressed and solved all the problematic points raised by the indigenous communities in relation to the ILO Convention No. 169. Besides recognizing the right to self-determination and the subsequent definition of 'people', it provides in Article 26 that 'indigenous people have the right to the lands, territories and resources which they have traditionally owned, occupied or otherwise used or acquired ${ }^{65}$ This stands in contrast with Articles 14 of the ILO Convention No. 169 that recognizes such right but only 'over the lands which they traditionally occupy, ${ }^{66}$ meaning that they currently occupy. Furthermore, the importance of the participation, rather than just the consultation, of indigenous people in any matter that can affect them is reiterated and underlined throughout all the declaration. That said, the UNDRIP remains an unenforceable instrument for its non-binding nature.

In light of the above, it is possible to conclude that the UNDRIP is a significant advancement for indigenous property rights compared to the ILO Convention No. 169 and contained specific provisions that could guide the ECtHR toward a more progressive

\footnotetext{
${ }^{63}$ ibid, 65-66.

${ }^{64}$ UNDRIP, Article 3.

${ }^{65}$ ibid, Article 26.

${ }^{66}$ ILO Convention 169, Article 14.
} 
judicial application of Article 1 Protocol 1 ECHR to indigenous people. To this extent, the transformation of the UNDRIP in a binding treaty could be a good step forward for a wider recognition of indigenous rights. This process should also occur with an active involvement of the regional systems, which should be invested of the ultimate role of enforcing the treaty at the regional level. Obviously, in order to be effective it will need a wide number of ratifications, definitely more than the 22 currently held by the ILO Convention. However, considering the different reception from indigenous community and specialized NGOs ${ }^{67}$ and the high number of ratification of the declaration so far, this new instrument could register a higher ratification rate.

Lastly, a solution to fragmentation would be an increased cross-referencing between regional courts. If the European Court started looking at and referring to the case-law of the IACtHR on indigenous property rights, it would realize that the principles established by the Inter-American Court are easily transferrable and applicable to the European context as well. Considering that the letter of the property right provision in the ECHR and ACHR are mostly the same, the European Court should have no problems in adopting part of the Inter-American reasoning to adequately protect indigenous rights in Europe. However, this new route would entail a deep change of attitude of the ECtHR toward other regional jurisprudence and a different legal approach to its own jurisprudence. Still, the role of civil society and of NGOs specialised in indigenous rights is crucial in lobbying for this to happen and for making the European Court aware of the fact that, on certain matters, it should follow the example of other regional systems that have established considerably higher standards of protection.

\footnotetext{
${ }^{67}$ Cfr the reception of the UNDRIP by "First Peoples Worldwide", the "International Work Group for Indigenous Affair", "Cultural Survival" and "Native Planet".
} 


\section{Conclusion}

Judicial fragmentation is currently affecting the regional case-law on indigenous property rights. The different approach toward the issue, caused by legal, social and cultural variables determines divergent judicial outcomes of the European Court of Human Rights, the Inter-American Court of Human Rights and the African Commission of Human and People's Rights.

Considering the possible consequences that this phenomenon could determine, it is important to think and elaborate feasible solutions. Among them, the strengthening of the role of civil society and NGOs is certainly a key aspect. However it can produce results only if accompanied by an effort in changing the approach of the European Court to crossreferencing and judicial borrowing from other regional systems. Lastly, the achievements of the UN Declaration on the Rights of Indigenous People could be further increased by the transformation of the Declaration into a binding Treaty with an active participation of regional systems in the drafting and enforcement stages. 